\title{
Sanja Filipović
}

GENDER OF CHILDREN AND PRESCHOOL PROGRAM MODELS AS FACTORS IN PRESCHOOL CHILDREN'S CREATIVITY

\author{
University of Novi Sad, Academy of Arts \\ Đure Jakšića 7, 21000, Novi Sad, Serbia \\ E-mail: argus4@open.telekom.rs
}

\begin{abstract}
One of the key goals in preschool education is fostering children's creativity and child making art. This process has different approaches depending on understanding the sense and significance of arts education with preschool children. This research is fragment of one lager research work results of which have already been represented to the scientific public. Our research has begun with an assumption that certain factors can encourage development of creativity with the youngest children. It was particularly analysed the influence of Models in the preschool program that was performed in daycare institutions in Serbia for more than two decades including the gender as one of examined factors. The Williams Creativity Test was applied as well known method in Serbia and worldwide. Evaluation included differences between strategies the programs were based on, its aims, contents, methods, and effects established by certain scientific procedures. There was particularly included the level of creativity with children in the field of art makingBased on the obtained results in this and other research works we can conclude that children need full-valued and systematic support in the most important time of their development, especially when we speak of creative development.
\end{abstract}

Keywords: creativity; preschool child; methods in arts education; educational models.

\section{ФИЛИПовИч СаНЯ $\mid$ ГЕНДЕРНЫЕ ОСОБЕННОСТИ И МОДЕЛИ ОБРАЗОВАТЕЛЬНЫХ ПРОГРАММ КАК УСЛОВИЯ РАЗВИТИЯ ТВОРЧЕСТВА ДОШКОЛЬНИКОВ}

Нови-Садский университет, Академия художеств ул. Джуры Якшича 7, 21000 Нови-Сад, Сербия

E-mail: argus4@open.telekom.rs

\begin{abstract}
Аннотация. Одной из ключевых целей в дошкольном образовании является содействие детскому творчеству. Существуют различные подходы к данной проблеме в зависимости от понимания смысла и значимости дошкольного художественного образования. Данное исследование является частью одного экспериментального исследования, результаты которого уже были представлены научной общественности. Наше исследование началось с предположения, что определенные факторы могут способствовать развитию творчества дошкольников. В частности, было проанализировано влияние различных программ, которые реализовывали в детских садах Сербии более двух десятилетий, а также гендерный фактор как один из рассмотренных условий. В нашем исследовании был использован тест на творчество Уильямса. Изучение проблемы предполагало под собой
\end{abstract}


анализ стратегий, на которых основывались программы: ее целей, содержания, методов и условий. Особое внимание уделялось уровню детского творчества в процессе исследования. Основываясь на полученных результатах исследования, мы можем заключить, что дошкольники нуждаются в полноценной и систематической поддержке в самое важное время своего развития, особенно когда мы говорим о развитии детского творчества.

Ключевые слова: творчество, дошкольник, методы в художественном образовании, образовательные модели.

Introduction. Many upbringing models have been created through history critically different in their goals, contents and modes of their performance. The upbringing system finds its application in programs of upbringingeducational work especially including behavioural approach embedded in the academic framework studding the youngest and in its most extreme form characterises programs in totalitarian systems having the forms of dressage tending to shape children according to requests of an official state or dominant elite while failing to consider children`s needs, abilities and interests. The paradigm in this approach is tutor, a pottery man, who makes of non-living matter what was ordered to him [10]. Other stream belongs to the framework of humanistic principles where starting approach is an attitude that children carry developmental potentials that should be freed by education. In such process a child participates willingly and actively expressing characteristics of own personality including creativity as the most important feature. This paradigm includes tutor as a gardener who cultivates flowers, i.e. children taking care of their personal and different needs and abilities [9].

During last few decades in Serbia in preschool programs have been developed concepts and models embedded in the humanistic ideas of education. However, there have been recognised certain differences among teacher's activities especially in fostering creativity and art making with preschool children that originate in basic understanding of education significance and sense especially in domain of arts teaching with certain differences and repercussions to children's creative expression. Consequently there has occurred need to identify differences in preschool children creativity and influencing factors. This research followed up with factors such as children's gender and program's model that teachers achieve in their work in preschool institutions through Essentials of preschool program of upbringing/educational work [8].

Materials and methods. The basic aim of this work was to perceive effect of factors such as gender in children attending the program model $\mathrm{A}$ and children attending the program model B through analysis of children`s drawings included in test of divergent and creative thinking while bringing the facts that were established in relation with characteristics of the child making art and teaching methodology actions and concepts of the educational program.

The main task was to examine relations between educational program and characteristics of the child making art considering the gender in order to establish that this factor has an influence on development of the child making art. The task in this research is: To establish whether and in which way and to which extent factors such as the gender in children, as program's model (or teacher who works on it), effect development of children's creativity.

Independent variables in this research were the following: 1 . Pedagogy concept of the upbringing/educational program applied in day cares especially arts education program that is perceived through model $A$ and model B Basics of the upbringing-educational work; 2 . Gender of children. Dependable variables in this research appears through results achieved by the children in this research framework including children's creativity perceived through analysis of the child's drawing per components: 1 . Productivity; 2. Flexibility; 3. Authenticity; 4. Asymmetry/Symmetry and richness of vocabulary (verbal comment).

The starting hypothesis in this research is that children`s creativity mirrored in features of 
the art expressions perceived through components of creativity, is affected by the following: pedagogic concept of educational program in work achieved in day cares (particularly the arts education program) and gender in children that have been participated this research. The hypothesis has been formulated in the zero form and it worded: Factors such as gender in children and program's model (or teacher who works on it) do not influence development of the children's creativity. The basic hypothesis in this research is scientifically founded in the experience of teachers and arts pedagogies including findings of other authors. At the same time it opens questions about causalconsequential links and mutual conditionality in effects of certain factors that partially have been discovered through this research work.

Application in practice of various program types means action research fully depending on descriptive method and separate form of this method ex-post-facto procedure that is different from classical experiment with parallel groups due to lack of initial condition data that is compensated by systemic monitoring and describing relevant processes per phases. Regarding the fact that entire population of six years old children was included in preschool program, it was not possible to form a control group of children who have not participated day care institutions and to compare it with those who were in day care. However, the foreseen procedure has certain advantages characterised as research in natural conditions in vivo with encompassing factors assumed that may have an impact to child making art and creativity development that would be hardly to perform in laboratory conditions.
On the basis of the operational plan as result of agreement by researcher and teachers on time and dynamics of the art activities realization in the group the implemented standardized instrument enabled statistical processing the data and conclusion making regarding the basic hypothesis. On the basis of differences occurred in regard to characteristics of children`s art expression depending on the concept of $\mathrm{Ba}$ sics of program there were monitored their characteristics through creativity components (Authenticity, fluency, flexibility, as well as asymmetry/symmetry and richness of vocabulary (verbal comment) and related with the gender as factor and children`s results on applied test.

The research sample is of children who attended day care institutions during 2007/2008. Total number of children making the sample is 444 children. Testing has included children from eight (8) day cares in Belgrade from the following institutions: kindergarten 11 April - New Belgrade Municipality and kindergarten Dr. Sima Milošević - Zemun Municipality. Testing of participants has been done in day care institutions in the period from February to April 2008 in Belgrade. The sample included 222 boys and 222 girls in the age of 5 to 7 years; the equal number of children who were in preschool groups included in the upbringing-educational program of Model A Basics of program (222 children) and equal number of children who were in day care groups included in the upbringing-educational program of Model B Basics of program (222 children) (making the sample quota-like in addition to intentional) (Table 1).

Table 1

Williams test of creative abilities - quota sample of children per gender

Таблица 1

Тест Вильямса для комплексной диагностики креативности - выборка квот детей в зависимости от пола

\begin{tabular}{|c|c|c|c|}
\hline $\begin{array}{c}\text { Gender } \\
\text { Program basics }\end{array}$ & B model & A model & Sample total \\
\hline M & 111 & 111 & $\mathbf{2 2 2}$ \\
\hline F & 111 & 111 & $\mathbf{2 2 2}$ \\
\hline Total & $\mathbf{2 2 2}$ & $\mathbf{2 2 2}$ & $\mathbf{4 4 4}$ \\
\hline
\end{tabular}


Collected data about the children included the following: age of a child (date of birth based on which is calculated the actual age of a child at testing day); gender; upbringingeducational institution child attended to; Model of upbringing-educational program that was performed with child.

Research technique during the process of data collecting has included research testing procedure. Characteristics of creative-divergent thinking of each child in the group and educational group as whole were established by the standardised research instrument titled: Williams Modified creative test.

The used instrument was in accordance with method and techniques of this research segment for both groups of participants (children included in the Model A and children in the Model B). the Williams creative test [15] is one modified standardised test of children's art expressions for children between 5-8 years of age. Elena Tunic has adapted the test during her three years research work and she provided certain norms per age using original American Williams test ([16]. The estimator has relied to the following norms according to the definition by Elena Tunik:

1. Productivity (Fluency) - independently from the content of drawings it is counted each drawn drawing. Theoretical assumption is that creative individuals produce more. A child worksfast and prolifically.

2. Flexibility - it is perceived the number of changes in the content of drawings or change of categories. Creative individuals make changes more frequently than conforming to regular procedures, ways or one kind of category of drawings. The way of thinking is flexible. The child is able to produce different ideas, changes its position, and observes things in a new way.

3. Originality - it is evaluated through position of drawing in relation with assigned stimulus - line or drawing inside or outside in relation with assigned drawing or line. In each square is assigned a line or figure representing or becoming a limit for less creative individuals. The most original are those who draw inside and outside the assigned figure creating sensible synthesis of given forms and which are not disturbed with given contour.

4. Asymmetry - symmetry - points to position of details on such drawing whether it is defined as symmetric or asymmetric. Asymmetric selections were evaluated as an expression of creativity.

5. Title - represents richness of the vocabulary and words that were used in titles, ability to picturesque expression of the essence of drawing, direct description of what is made on drawing, or revealing hidden sense, sub-text [7, pp. 355-365].

According to place and mode of conducting the research it is possible to say that implemented procedure was natural due to certain conditions that were unchanged. Testing was conducted in cooperation with teachers working in the group of children and number of children in the group was the same as in their regular work enabling the same age in average (preschool group), kind of equalized time of test performing in both groups (meaning the period of a day when children are in day care, so testing was organised in morning hours when children are fresh for work). Testing time for children of 5-7 years was 25-30 minutes. Test assignment helped us to learn the children's abilities in creative expressing by drawings. Children were instructed to work quickly and to try to draw such unusual things that nobody else can imagine. When drawing was completed, children were stimulated to think about each own piece of work giving names to it in order to clarify the content by title and to reveal its meaning and sense. In order to make test valid and to make all children to put maximum efforts in process of work the researcher has established warm and honest relation with children. There must not be any suggestion neither by teacher nor by other children, so they were disabled to show their drawings to anybody else until it was done.

In the data processing dominant were non-parametrical statistical procedures. It had been assumed to calculate computing values obtained by assessments which were actualised as much as possible thanks to clearly defined categories and with participation by qualified estimators. In processing the data resulting in 
research by Williams`creativity test there were applied descriptive methods. Each variable was calculated for the measures of central tendency (mode, median, arithmetic mean) and dispersion measures (variation span, quarter deviation, variant and standard deviation). In order to test hypothesis there has been used student's Ttest for significance of differenced of arithmetic means between model A and model B including previously calculated descriptive parameters. In order to perceive effects of monitored factors there has been formed quote sample group of children according to gender (equal number of girls and equal number of boys). For factor gender and factor program model there was applied F-test (one-factor and two-factor variants analysis)

There were calculated results among the following samples:

1. Male children and female children within the model A

2. Male children and female children within the model $\mathrm{B}$

3. Female children within the model A and female children within the model $\mathrm{B}$

4. Male children within the model A and male children within the model B

5. Male children within both models (A and $B$ ) and female children within both models (A and B)

Results. 1) Male children and female children in the model A

Table 2

Calculated values for score values of children according the gender - measure of central tendency and measure of dispersion for male children and female children in the model $A$

Таблица 2

Расчет показателей у детей по гендерному признаку - основные тенденции и распределение по половому признаку у мальчиков и девочек в модели А

\begin{tabular}{|l|c|c|}
\hline Descriptive method & $\begin{array}{c}\text { A model } \\
\text { Male }\end{array}$ & $\begin{array}{c}\text { A model } \\
\text { Female }\end{array}$ \\
\hline a S & 68.252 & $\mathbf{6 9 . 7 8 3}$ \\
\hline mod & 72 & $\mathbf{6 8}$ \\
\hline median & 69 & $\mathbf{7 0}$ \\
\hline Max & 89 & $\mathbf{8 8}$ \\
\hline Min & 25 & $\mathbf{3 3}$ \\
\hline RV & 64 & $\mathbf{5 5}$ \\
\hline Var & 87.426 & $\mathbf{7 9 . 5 1 6}$ \\
\hline SD & 9.350 & $\mathbf{8 , 9 1 7}$ \\
\hline V & $13.6 \%$ & $\mathbf{1 2 . 7 \%}$ \\
\hline Q1 & 64 & $\mathbf{6 5 . 5}$ \\
\hline Q3 & 73 & $\mathbf{7 6}$ \\
\hline Vq & $\mathbf{0 . 0 6 5}$ & $\mathbf{0 . 0 7 4}$ \\
\hline
\end{tabular}

Based on the review of table (Table 2) with descriptive parameters for male and female within the model it is possible to spot the following:

Regarding central tendency measures there is difference between the arithmetic mean (M) for these two samples. Average score in male children in the A model $\mathrm{M}=68.252$ is lower than average score in female children in the A model $\mathrm{M}=69.783$ in favour of female children. In both samples, the modes (Mo) or scores the most often occurs in the sample are different in a way that in male children $\mathrm{Mo}=72$ having deviations from the arithmetic mean, and in female children $\mathrm{Mo}=68$ having no significant deviations from the arithmetic mean. Median, or score that discriminates statistical mass of sample to half-and-half, in male children $\mathrm{Me}=69$ and female children $\mathrm{Me}=70$.

Regarding dispersion measures there is maximum score (Max) in these two samples statistically not significantly different. In male 
children in the model A Max=89 and female children in the model A Max=88. With minimum score (Min) there is greater difference in male children Min=25 and in female children Min=33. These differences between maximum and minimum scores are perceived through calculated value of the variation span (RV) where in male children $R V=64$ and in female children $\mathrm{RV}=55$.

Standard deviation $(\sigma)$ representing deviation of individual scores from the arithmetic mean in both samples is significantly different. In male children $\sigma=9.35$ and in female children $\sigma=8.917$ where scores in male children deviate more from the arithmetic mean in comparison with scores in female children within the A model.

On the basis of the variation coefficient (V) used to perceive percentage value of standard deviation (or comparison of scores variability) according to the arithmetic mean as a basis, the variation coefficient in male children is $\mathrm{V}=13.6 \%$ and in female children $\mathrm{V}=12.7 \%$. Therefore it is concluded that deviation from the arithmetic mean exists and the difference is poor in both samples in the A model. Regarding the inter-quarter variations $(\mathrm{Vq})$, the series in both samples do not show large deviations. In male children $\mathrm{Vq}=0.065$ and in female children $\mathrm{Vq}=0.074$.

Table 3

Student's T-table for Williams creativity test - Test of difference of the arithmetic mean between female children and male children in the A model

\section{Таблица результатов теста Вильямса - среднеарифметические показатели у девочек и мальчиков в модели А}

\begin{tabular}{|l|l|l|l|l|l|}
\hline \multicolumn{7}{|l|}{ test } \\
\hline Variable & $\boldsymbol{N}$ & $\boldsymbol{t}$ & $\boldsymbol{d} \boldsymbol{f}$ & $\boldsymbol{t} \boldsymbol{v}$ & $\boldsymbol{p}$ \\
\hline Results in female children and result & 220 & 1.248 & 200 & 1.64 & $<\mathbf{0 . 0 5}$ \\
\hline $\begin{array}{l}\text { in male children within the model A } \\
\text { of Williams creativity test }\end{array}$ & & & $\infty$ & 2.32 & $<\mathbf{0 . 0 1}$ \\
\hline
\end{tabular}

Note: $\mathrm{N}$ - number of participants; $\mathrm{t}$ - Student`s test of significance of differences; $\mathrm{df}$ - freedom grade; $\mathrm{tv}$ - value from tables for freedom grade; $\mathrm{p}$ - statistical significance level

Calculated values of T-statistics for significance of differences of the arithmetic mean in children's results of the Williams creativity test between female children and male children in the model A and calculated values for signif- icance of differences are lower than in tables, or $\mathrm{t}=1.248<\mathrm{t}=0.05 ; 220=1.645$ and it can bring a conclusion that differences of the arithmetic mean are not statistically significant between these two samples (Table 3).

\section{2) Male children and female children in the model B}

Calculated values for score values of children according the gender - measure of central tendency and measure of dispersion for male children and female children in the model $B$

Расчет показателей у детей по гендерному признаку - основные тенденции и распределение по половому признаку у мальчиков и девочек в модели В

\begin{tabular}{|l|c|c|}
\hline Descriptive methods & $\begin{array}{c}\text { B model } \\
\text { Male }\end{array}$ & $\begin{array}{c}\text { B model } \\
\text { Female }\end{array}$ \\
\hline A s & 74.945 & $\mathbf{7 5 . 7 5 6}$ \\
\hline mod & 77 & $\mathbf{7 8}$ \\
\hline median & 75 & $\mathbf{7 6}$ \\
\hline
\end{tabular}




\begin{tabular}{|l|c|c|}
\hline Max & 92 & $\mathbf{9 9}$ \\
\hline Min & 50 & $\mathbf{6 0}$ \\
\hline RV & 42 & $\mathbf{3 9}$ \\
\hline Var & 52.997 & $\mathbf{5 1 . 0 5 8}$ \\
\hline SD & 7.279 & $\mathbf{7 . 1 4 5}$ \\
\hline V & $9.7 \%$ & $\mathbf{9 . 4 \%}$ \\
\hline Q1 & 69.5 & $\mathbf{7 0}$ \\
\hline Q3 & 80 & $\mathbf{8 0}$ \\
\hline Vq & $\mathbf{0 . 0 7 0}$ & $\mathbf{0 . 0 6 6}$ \\
\hline
\end{tabular}

On the basis of tables (Table 4) with descriptive parameters for male and female children in the model $\mathrm{B}$ it is possible to spot the following:

With measures of the central tendency there is difference between the arithmetic mean (M) for these two samples. Average score in male children in the B model $\mathrm{M}=74.945$ and it is lower than average score in female children in the model $B$ where $M=75.756$ and in favour of female children. In both samples, modes (Mo) or scores that the most often occur in the sample are slightly different, where in male children $\mathrm{Mo}=77$ having deviations from the arithmetic mean; and in female children $\mathrm{Mo}=78$ with modes in both samples that significantly deviate from their arithmetic mean. Median, or score that discriminates statistical mass of sample to half-and-half, in male children $\mathrm{Me}=75$ and female children $\mathrm{Me}=76$.

Regarding dispersion measures there is maximum score (Max) in these two samples statistically not significantly different. In male children in model B Max=92 and female children in model B Max $=99$. With minimum score (Min) there is greater difference in male children Min=50 and in female children Min=60. These differences between maximum and minimum scores are perceived through calculated value of the variation span $(\mathrm{RV})$ where in male children $\mathrm{RV}=42$ and in female children $\mathrm{RV}=39$ in the model B.
Standard deviation $(\sigma)$ representing deviation of individual scores from the arithmetic mean in both samples is significantly different. In male children $\sigma=7.279$ and in female children $\sigma=7.145$ where scores in male children deviate a bit more from the arithmetic mean in comparison with scores in female children within the B model.

On the basis of variation coefficient $(\mathrm{V})$ used to perceive percentage value of standard deviation (or comparison of scores variability) according to the arithmetic mean as a basis, the variation coefficient in male children is $\mathrm{V}=9.7 \%$ and in female children $\mathrm{V}=9.4 \%$ in the $\mathrm{B}$ model. Therefore it is concluded that deviation from the arithmetic mean exists but the difference is poor in both samples in the B model. Regarding the inter-quarter variations $(\mathrm{Vq})$, the series in both samples do not show large deviations. In male children $\mathrm{Vq}=0.070$ and in female children $\mathrm{Vq}=0.066$.

Calculated values of T-statistics for significance of differences of the arithmetic means in children's results of the Williams creativity test between female children and male children in the model $\mathrm{B}$, and calculated values for significance of differences is lower than in tables, or $\mathrm{t}=0.837<\mathrm{t}=0.05 ; 220=1.645$ and it can bring a conclusion that differences of the arithmetic means are not statistically significant between these two samples (Table 5). 
Table 5

Student's T-table for Williams creativity test - Test of difference of arithmetic means between female children and male children in the $B$ model

Таблица 5

Таблица результатов теста Вильямса - среднеарифметические показатели у девочек и мальчиков в модели В

\begin{tabular}{|l|l|l|l|l|l|}
\hline \multicolumn{1}{|c|}{ T test } \\
\hline \multicolumn{1}{|c|}{ Variable } & $\boldsymbol{N}$ & $\boldsymbol{t}$ & $\boldsymbol{d}$ & \multicolumn{1}{c|}{$\boldsymbol{t} \boldsymbol{v}$} & \multicolumn{1}{c|}{$\boldsymbol{p}$} \\
\hline $\begin{array}{l}\text { Results in female children and result } \\
\text { in male children within the model A } \\
\text { of Williams creativity test }\end{array}$ & 220 & 0.837 & 200 & 1.64 & $<\mathbf{0 . 0 5}$ \\
\cline { 5 - 6 } & & & $\infty$ & 2.32 & $<\mathbf{0 . 0 1}$ \\
\cline { 3 - 5 } & & & & $\mathbf{3 . 2 9}$ & $<\mathbf{0 . 0 0 1}$ \\
\hline
\end{tabular}

Note: $\mathrm{N}$ - number of participants; $\mathrm{t}$ - Student`s test of significance of differences; $\mathrm{df}$ - freedom grade; $\mathrm{tv}$ - value from tables for freedom grade; $\mathrm{p}$ - statistical significance level

3) Female children in the model $B$ and female children in the model $A$

Table 6

Calculated values for scores of the children per gender - measure of central tendency and measure of dispersion for female children in the model B and female children in the model A

Таблица 6

Расчет показателей у детей по гендерному признаку - основные тенденции и распределение по половому признаку у девочек в моделях В и А

\begin{tabular}{|l|c|c|}
\hline Descriptive methods & $\begin{array}{c}\text { B model } \\
\text { Female }\end{array}$ & $\begin{array}{c}\text { A model } \\
\text { Female }\end{array}$ \\
\hline a s & 75.756 & $\mathbf{6 9 . 7 8 3}$ \\
\hline mod & 78 & $\mathbf{6 8}$ \\
\hline median & 76 & $\mathbf{7 0}$ \\
\hline Max & 99 & $\mathbf{8 8}$ \\
\hline Min & 60 & $\mathbf{3 3}$ \\
\hline RV & 39 & $\mathbf{5 5}$ \\
\hline Var & 51.058 & $\mathbf{7 9 . 5 1 6}$ \\
\hline SD & 7.145 & $\mathbf{8 . 9 1 7}$ \\
\hline V & $9.4 \%$ & $\mathbf{1 2 . 7 \%}$ \\
\hline Q1 & 70 & $\mathbf{6 5 , 5}$ \\
\hline Q3 & 80 & $\mathbf{7 6}$ \\
\hline Vq & $\mathbf{0 . 0 6 6}$ & $\mathbf{0 . 0 7 4 2}$ \\
\hline
\end{tabular}

Based on the review of tables (Table 6) with descriptive parameters for female children in the model B and female children in the model A, it is possible to comprehend the following:

With measures of the central tendency there is difference between the arithmetic means (M) for these two samples. Average score in female children in the $\mathrm{B}$ model $M=75.756$ and it is higher than average score in female children in the model A where $\mathrm{M}=69.783$ and in favour of female children from the B model. In both samples, modes
(Mo) or scores the most often occur in the sample are significantly different, where in female children in the $\mathrm{B}$ model $\mathrm{Mo}=78$ having deviations from the arithmetic mean; and in female children in the model $\mathrm{A}$ Mo=68 with modes in both samples that deviate from their arithmetic mean and are mutually different. Median, or score that discriminates statistical mass of sample to half-and-half, in female children in the model $\mathrm{B} \mathrm{Me}=76$ and female children in the model $\mathrm{A} \mathrm{Me}=70$. 
Regarding dispersion measures there is maximum score (Max) in these two samples statistically significantly different. In female children in model B Max=99 and female children in model A Max $=88$. With minimum score (Min) there is greater difference in female children in the B model with Min=50 and in female children in the A model Min=33. These differences between maximum and minimum scores are perceived through calculated value of the variation span (RV) where in female children in the model $B$ have $R V=39$ and in female children in the model A have RV=55.

Standard deviation $(\sigma)$ representing deviation of individual scores from the arithmetic mean in both samples is significantly different. In female children in the model $B \sigma=7.145$ and in female children in the model $\mathrm{A} \sigma=8.917$ where scores in female children in the model A deviate a bit more from the arithmetic mean in comparison with scores in female children in the B model.

On the basis of variation coefficient $(\mathrm{V})$ used to perceive percentage value of standard deviation (or comparison of scores variability) according to the arithmetic mean as a basis, the variation coefficient in female children in the $B$ model is $\mathrm{V}=9.4 \%$ and in female children in the model A V $=12.7 \%$. Therefore it is concluded that deviation from the arithmetic mean exists and deviation is grater in the A model than in the $\mathrm{B}$ one. Regarding the inter-quarter variations (Vq), the series in both samples do not show large deviations. In female children in the model $\mathrm{B} \mathrm{Vq}=0.066$ and in female children in the model $\mathrm{A}$ the $\mathrm{Vq}=0.074$.

Calculated values of T-statistics for significance of differences of the arithmetic means in children's results of the Williams creativity test between female children in the model B and female children in the model A, and calculated values for significance of differences is higher than in tables, or $\mathrm{t}=5.077<\mathrm{t}=0.001 ; 220=3.29$ and it can bring a conclusion that differences of the arithmetic means are statistically significant between these two samples in favour to the female children in the model B (Table 7).

Table 7

\section{Student's T-table for Williams creativity test - Test of difference of arithmetic means between female children in the model $B$ and male children in the A model}

Таблица результатов теста Вильямса - среднеарифметические показатели у девочек в модели В и мальчиков в модели А

\begin{tabular}{|l|l|l|l|l|l|}
\hline \multicolumn{7}{|c|}{ test } \\
\hline Variables & $\boldsymbol{N}$ & $\boldsymbol{t}$ & $\boldsymbol{d} \boldsymbol{f}$ & $\boldsymbol{t} \boldsymbol{v}$ & $\boldsymbol{p}$ \\
\hline Results in female children and result & 220 & 5.077 & 200 & 1.64 & $<\mathbf{0 . 0 5}$ \\
$\begin{array}{l}\text { in male children within the model B } \\
\text { of Williams creativity test }\end{array}$ & & & $\infty$ & 2.32 & $<\mathbf{0 . 0 1}$ \\
\cline { 5 - 7 } & & & & $\mathbf{3 . 2 9}$ & $<\mathbf{0 . 0 0 1}$ \\
\hline
\end{tabular}

Note: $\mathrm{N}$ - number of participants; $\mathrm{t}$ - Student's test of significance of differences; $\mathrm{df}$ - freedom grade; $\mathrm{tv}$ - value from tables for freedom grade; $\mathrm{p}$ - statistical significance level

In the $\mathrm{t}-$ test there was spotted significant difference between the arithmetic mean in both models for female children in the model $\mathrm{B}$ and female children in the model $\mathrm{A}$, but $\mathrm{t}$ - test could not emphasize reasons of this difference due to which reason was implemented the $\mathrm{F}-$ test (factor analysis of variance) that intended to show whether the selection of model Program Base was the factor that influenced obtained differences.
Regarding the realized value of $\mathrm{F}$ statistics is higher than limit value, or: $\mathrm{D}=30.32>\mathrm{F} 001 ; 1 ; 220=6.64$, it is possible to conclude with error risk of 0.01 that controlled factor programme model (or teacher that works accordingly) systematically stimulatesthe results of creativity in preschool children and in favour of female children in the $\mathrm{B}$ model (Table 8). 
One-factor variance analysis - F-test

Таблица 8

Результаты анализа по одному фактору - F-тест

\begin{tabular}{|l|c|c|c|c|c|}
\hline Source of variability & $N$ & $F$ & $d f 1 / d f 2$ & $t v$ & $p$ \\
\hline $\begin{array}{l}\text { Factor (between groups of female children in the } \\
\text { model A and female children in the model B) / } \\
\text { Residual (within groups of female children in the } \\
\text { model A and female children in the model B) }\end{array}$ & 222 & $\mathbf{3 0 . 3 2 8}$ & $\mathbf{1 / 2 2 0}$ & $\mathbf{6 . 6 4}$ & $<\mathbf{0 . 0 1}$ \\
\hline
\end{tabular}

Note: $\mathrm{N}$ - number of participants; $\mathrm{F}$ - value of variance; df1/df 2 - grade of freedom for factor and residual; tv - value in table of freedom grade; $\mathrm{p}$ - statistical significance level

4) Male children in the model $B$ and male children in the model $A$

Table 9

Calculated values for scores of children regarding gender - measure of central tendency and measure of dispersion for male children in the model $B$ and male children in the model $A$

Расчет показателей у детей по гендерному признаку - основные тенденции и распределение по половому признаку у мальчиков в моделях В и А

\begin{tabular}{|l|c|c|}
\hline Descriptive methods & $\begin{array}{c}\text { B model } \\
\text { Male }\end{array}$ & $\begin{array}{c}\text { A model } \\
\text { Male }\end{array}$ \\
\hline A s & 74.945 & $\mathbf{6 8 . 2 5 2}$ \\
\hline mod & 77 & $\mathbf{7 2}$ \\
\hline median & 75 & $\mathbf{6 9}$ \\
\hline Max & 92 & $\mathbf{8 9}$ \\
\hline Min & 50 & $\mathbf{2 5}$ \\
\hline RV & 42 & $\mathbf{6 4}$ \\
\hline Var & 52.99 & $\mathbf{8 7 . 4 2 6}$ \\
\hline SD & 7.279 & $\mathbf{9 . 3 5 0}$ \\
\hline V & $9.7 \%$ & $\mathbf{1 3 . 6 \%}$ \\
\hline Q1 & 69.5 & $\mathbf{6 4}$ \\
\hline Q3 & 80 & $\mathbf{7 3}$ \\
\hline Vq & $\mathbf{0 . 0 7 0}$ & $\mathbf{0 . 0 6 5}$ \\
\hline
\end{tabular}

Based on the review of tables (Table 9) with descriptive parameters for male children in the model B and male children in the model $\mathrm{A}$, it is possible to comprehend the following.

With measures of the central tendency there is difference between the arithmetic mean (M) for these two samples. Average score in male children in the $\mathrm{B}$ model $\mathrm{M}=75.945$ is higher than average score in male children in the model A where $\mathrm{M}=68.252$ and in favour of male children from the B model. In both samples, modes (Mo) or scores the most often occur in the sample are significantly different, where in male children in the B model $\mathrm{Mo}=77$ and in male children in the model $\mathrm{A} M o=72$ with modes in both samples that deviate from their arithmetic mean and are mutually different. Median, or score that discriminates statistical mass of sample to half-and-half, in male children in the model $\mathrm{B} \mathrm{Me}=75$ and male children in the model $\mathrm{A} \mathrm{Me}=69$.

Regarding dispersion measures there is maximum score (Max) in these two samples statistically significantly different. In male children in model B Max=92 and male children in model $\mathrm{A}$ Max $=89$. With minimum score 
(Min) there is greater difference in male children in the B model with Min=50 and in male children in the A model Min=25. These differences between maximum and minimum scores are perceived through calculated value of the variation span $(\mathrm{RV})$ where in male children in the model $B \mathrm{RV}=42$ and in male children in the model A RV=64.

Standard deviation $(\sigma)$ representing deviation of individual scores from the arithmetic mean in both samples is significantly different. In male children in the model $\mathrm{B} \sigma=7.279$ and in male children in the model $\mathrm{A} \sigma=9.350$ where scores in male children in the model A deviate significantly more from the arithmetic mean in comparison with scores in male children in the B model.

On the basis of variation coefficient $(\mathrm{V})$ used to perceive percentage value of standard deviation (or comparison of scores variability) according to the arithmetic mean as a basis, the variation coefficient in male children in the $\mathrm{B}$ model is $\mathrm{V}=9.7 \%$ and in male children in the model A $\mathrm{V}=13.6 \%$. Therefore it is concluded that deviation from the arithmetic mean exists and deviation is grater in the A model than in the $\mathrm{B}$ one. Regarding the inter-quarter variations $(\mathrm{Vq})$, the series in both samples do not show large deviations. In male children in the model $\mathrm{B} \mathrm{Vq}=0.070$ and in male children in the model $\mathrm{A}$ the $\mathrm{Vq}=0.065$.

Calculated values of T-statistics for significance of differences of the arithmetic mean in children's results of the Williams creativity test between male children in the model $\mathrm{B}$ and male children in the model $\mathrm{A}$, and calculated values for significance of differences is higher than in tables, or $\mathrm{t}=5.95>\mathrm{t} 0.001 ; 220=3.29$ and it can bring a conclusion that differences of the arithmetic means are statistically significant between these two samples in favour of the male children in the model $\mathrm{B}$ (Table 10).

Table 10

\section{Student's T-table for Williams creativity test - Test of difference of arithmetic means between male children in the model $B$ and male children in the A model}

Таблица 10

\section{Таблица результатов теста Вильямса - среднеарифметические показатели у мальчиков} моделей В и А

\begin{tabular}{|l|l|l|l|l|l|}
\hline \multicolumn{7}{|c|}{$\boldsymbol{t}$ test } \\
\hline Variable & $\boldsymbol{N}$ & $\boldsymbol{t}$ & $\boldsymbol{d} \boldsymbol{f}$ & $\boldsymbol{t} \boldsymbol{p}$ \\
\hline Results of female children and male & 220 & 5.95 & 200 & 1.64 & $<\mathbf{0 . 0 5}$ \\
children in the model B at Williams & & & $\infty$ & 2.32 & $<\mathbf{0 . 0 1}$ \\
creativity test & & & & $\mathbf{3 . 2 9}$ & $<\mathbf{0 . 0 0 1}$ \\
\hline
\end{tabular}

Note: $\mathrm{N}$ - number of participants; $\mathrm{t}$ - Student`s test of significance of differences; $\mathrm{df}$ - freedom grade; $\mathrm{tv}$ - value from tables for freedom grade; $\mathrm{p}$ - statistical significance level

In the $\mathrm{t}$ - test there was spotted significant difference between the arithmetic mean in both models for male children in the model $\mathrm{B}$ and male children in the model $\mathrm{A}$, but $\mathrm{t}$ - test could not emphasize reasons of this difference due to which reason was implemented the F test (factor analysis of variance) that intended to show whether the selection of model Program Base was the factor that influenced obtained differences.
Regarding the realized value of $\mathrm{F}$ statistics is higher than limit value, or: $\mathrm{D}=35.417>\mathrm{F} 001 ; 1 ; 220=6.64$, it is possible to conclude with error risk of 0.01 that controlled factor programme model (or teacher that works accordingly) systematically stimulates the results of creativity in preschool children and in favour of male children in the $B$ model (Table 11). 
One-factor variance analysis - F-test

Результаты анализа по одному фактору - F-тест

\begin{tabular}{|l|c|c|c|c|c|}
\hline Source of variability & $N$ & $F$ & $d f 1 / d f 2$ & $t v$ & $p$ \\
\hline $\begin{array}{l}\text { Factor (between groups of male children in the } \\
\text { model A and male children in the model B)/ } \\
\text { Residual (within groups of children in the } \\
\text { model A and children in the model B) }\end{array}$ & 222 & 35.417 & $\mathbf{1 / 2 2 0}$ & $\mathbf{6 . 6 4}$ & $\mathbf{0 . 0 1}$ \\
\hline
\end{tabular}

Note: $\mathrm{N}$ - number of participants; $\mathrm{F}$ - value of variance; df1/df2 - grade of freedom for factor and residual; $t v$ - value in table of freedom grade; $p$ - statistical significance level

5) Male children in both models ( $A$ and $B$ ) and female children in both models ( $A$ and $B$ )

Table 12

Calculated values for children scores per gender - measure of central tendency and measure of dispersion for male children in both models and female children in both models

Таблица 12

Рассчитанные значения по гендерному признаку - основные тенденции и распределение у мальчиков обеих моделей и девочек обеих моделей

\begin{tabular}{|l|c|c|}
\hline Descriptive methods & Male children in both models & Female children in both models \\
\hline A s & 71.599 & $\mathbf{7 2 . 7 7 0}$ \\
\hline mod & 69 & $\mathbf{6 8}$ \\
\hline median & 72 & $\mathbf{7 3}$ \\
\hline Max & 92 & $\mathbf{9 9}$ \\
\hline Min & 25 & $\mathbf{3 3}$ \\
\hline RV & 67 & $\mathbf{6 6}$ \\
\hline Var & 81.146 & $\mathbf{7 3 . 9 5 1}$ \\
\hline SD & 9.008 & $\mathbf{8 . 5 9 9}$ \\
\hline V & $12.5 \%$ & $\mathbf{1 1 . 8 \%}$ \\
\hline Q1 & 68 & $\mathbf{6 8}$ \\
\hline Q3 & 77 & $\mathbf{7 8}$ \\
\hline Vq & $\mathbf{0 . 0 6 2}$ & $\mathbf{0 . 0 6 8}$ \\
\hline
\end{tabular}

Based on the review of tables (Table 12) with descriptive parameters for male children in both models ( $\mathrm{A}$ and $\mathrm{B}$ ) and female children in both models ( $\mathrm{A}$ and $\mathrm{B}$ ), it is possible to comprehend the following:

With measures of the central tendency there is difference between the arithmetic mean (M) for these two samples. Average score in male children in both models $\mathrm{M}=71.599$ is a bit lower than average score in female children in both models where $\mathrm{M}=75.756$ and in favour of female children from both models.

In both samples modes (Mo) or scores the most often occur are approximately equal, where in male children in both models $\mathrm{Mo}=69$ and it has slighter deviations from the arithmetic mean; while in female children in both models $\mathrm{Mo}=68$ and significantly deviates from its arithmetic mean. Median, or score that discriminates statistical mass of sample to half-and-half, in male children in both models $\mathrm{Me}=72$ and female children in both models $\mathrm{Me}=73$.

Regarding dispersion measures there is maximum score (Max) in these two samples statistically significantly different. In male children in both models Max=92 and female children in both models Max $=99$. With minimum score (Min) there is greater difference in 
male children in both models with Min=25 and in female children in both models Min=33. These differences between maximum and minimum scores are perceived through calculated value of the variation span $(\mathrm{RV})$ where in male children in both models $\mathrm{RV}=67$ and in female children in both models $\mathrm{RV}=66$.

Standard deviation $(\sigma)$ representing deviation of individual scores from the arithmetic mean in both samples is significantly different. In male children $\sigma=9.008$ and in female children $\sigma=8.599$ where scores in female children in both models deviate less from the arithmetic mean in comparison with scores in male children in both models.

On the basis of variation coefficient $(\mathrm{V})$ used to perceive percentage value of standard deviation (or comparison of scores variability) according to the arithmetic mean as a basis, the variation coefficient in male children in both models is $\mathrm{V}=12.5 \%$ and in female children in both models $\mathrm{V}=11.8 \%$. Therefore it is concluded that deviation from the arithmetic mean is significant for each of samples but slightly different in between. Regarding the inter-quarter variations $(\mathrm{Vq})$, the series in both samples do not show large deviations. In male children in both models $\mathrm{Vq}=0.062$ and in female children in both models $\mathrm{Vq}=0.068$.

Calculated values of T-statistics for significance of differences of the arithmetic mean in children's results of the Williams creativity test between male children in both models and female children in both models, and calculated values for significance of differences is lower than in tables, or $\mathrm{t}=0.99>\mathrm{t} 0.05 ; 220=1.645$ and it can bring a conclusion that differences of the arithmetic means are not statistically significant between these two samples (Table 13).

\section{Student's T- table for Williams creativity test - Test of difference of arithmetic means between male children in both models and female children both models}

Таблица 13

\section{Таблица результатов теста Вильямса - среднеарифметические показатели у мальчиков обеих моделей и девочек обеих моделей}

\begin{tabular}{|c|c|c|c|c|c|}
\hline \multicolumn{6}{|c|}{$t$ test } \\
\hline Variable & $\bar{N}$ & $\bar{t}$ & $d f$ & $t v$ & $p$ \\
\hline \multirow{3}{*}{$\begin{array}{l}\text { Results of male children in both } \\
\text { models and female children in both } \\
\text { models at Williams creativity test }\end{array}$} & \multirow[t]{3}{*}{220} & \multirow[t]{3}{*}{0.99} & \multirow{3}{*}{$\begin{array}{l}200 \\
\infty\end{array}$} & 1.64 & $<0.05$ \\
\hline & & & & 2.32 & $<0.01$ \\
\hline & & & & 3.29 & $<0.001$ \\
\hline
\end{tabular}

Note: $\mathrm{N}$ - number of participants; $\mathrm{t}$ - Student`s test of significance of differences; $\mathrm{df}$ - freedom grade; $\mathrm{tv}$ - value from tables for freedom grade; $\mathrm{p}$ - statistical significance level

Regarding that have already been calculated differences of the arithmetic mean between different samples for the gender factor, as well as one-factor variance analysis, then also has been done two-factor variance analysis between factor age and factor gender.

In this F-test we have observed associated effects of 2 controlled factors - model and gender of children - to the children`s creativity meaning that effect of one factor (model A and model B) depends on the level of the second factor (female or male gender in children), as well there was observed the associated effect (interaction) of both factors.
The F-test results of two-factor variance analysis showed that realized value of the $\mathrm{F}$ statistics for F1 was higher than limit value, or $\mathrm{F} 1=65.717>\mathrm{F} 0.01 ; 1 ; 368=6.64$, and it was possible to conclude that controlled factor model systematically affected the results of the children at the Williams creativity test.

The F-test results of two-factor variance analysis showed that realized value of the $F$ statistics for $\mathrm{F} 2$ was lower than limit value, or $\mathrm{F} 2=2.247<\mathrm{F} 005 ; 1 ; 368=3.84$, and it was possible to conclude that controlled factor - gender did not affect the results of the children at the Williams creativity test. 
The F-test results of two-factor variance analysis also showed that there was no statistically significant difference relating to interaction - associated effects of two factors (model and gender) regarding the realized value of $\mathrm{F}$ statistics for F1,2 was lower than limit value, or: $\mathrm{F} 1,2=0.212<\mathrm{F} 005 ; 1 ; 368=3.84$ (Table 14).

Two-factor variance analysis - F-test

Table 14

Таблица 14

Результаты анализа по двум факторам - F-тест

\begin{tabular}{|l|l|l|l|l|l|l|l|}
\hline \multicolumn{1}{|c|}{ Source of variability } & $\boldsymbol{N}$ & $\boldsymbol{d f 1 / d f 2}$ & $\boldsymbol{F 1}$ & $\boldsymbol{F 2}$ & $\boldsymbol{F 1 , 2}$ & $\boldsymbol{t} \boldsymbol{c}$ & $\boldsymbol{p}$ \\
\hline $\begin{array}{l}\text { F1 = Model } \\
\text { F2 = Gender }\end{array}$ & 444 & $1 / 440$ & 65.717 & 2.247 & 0.212 & 3.84 & $<\mathbf{0 . 0 5}$ \\
$\begin{array}{l}\text { F1,2 =Interaction of fac- } \\
\text { tors- associated effects } \\
\mathbf{R}=\text { Residual (other fac- } \\
\text { tors) }\end{array}$ & & & $\mathbf{6 5 . 7 1 7}$ & - & - & $\mathbf{6 . 6 4}$ & $<\mathbf{0 . 0 1}$ \\
\hline
\end{tabular}

Note: $\mathrm{N}$ - number of participants; F- value of variance; df1/df2 - grade of freedom for factor and residual; tv - value in table of freedom grade; $\mathrm{p}$ - statistical significance level

It can be concluded that controlled factor gender does not systematically affect the children`s results at the Williams creativity test. On the basis of results we can see that controlled factors - model and gender in children in interaction do not systematically affect the children's results at the Williams creativity test, but the controlled factor - model is the one that systematically affects the children's results at the Williams creativity test; i.e. the selection of the model is the factor that significantly affects differences in the children's creativity and not their gender.

Discussions. Representatives of the humanistic approaches and ideas in Serbia are divided in two different streams such as maturation or self-development that is embedded in the thought of Jean Jacques Rousseau [13] whose attitude was that we would foster the child the best if we not foster at all, making the assignment of tutor minimised to the extent of just removing obstacles and restraining of any intervention that would be characterised as imposition. Such programs emphasize the child`s socialization and count on maturation mechanisms. The other stream mirrored in so-called cognitive-developmental programs is linked with the idea by the psychologist Jean Piaget [12]. Accordingly, with full respect of children's interests, needs and abilities, the full development of children should be performed by the systemic influence on a child because releasing children does not mean their freedom but capture in their own infantilism. Cognitive theories have their source in the holistic ideas and interdisciplinary as the base of integral development of the personality. Many empiric research works go in favour of this approach dealing with repercussions of such attitude to learning and development [2, pp. 145-150]. The childhood is precious period in life that should not be wasted but used to fulfill inherent children`s needs for learning and self-expressing through arts media. In this way relation between child and tutor is balanced, the child is independent as much as it can be, and extremes are avoided such as adult-centrism on one hand, and academic programs of pedagogycentrism patronised by the advocates of socialization-maturation program, on the other hand [4].

Described approaches and programs have found their application in conceptions of the arts education of preschool children. Behaviouristic approach is applied in programs of upbringing-educational work in day care institutions and teaching programs of arts culture in school system in Serbia where is still dominant imitative approach and actions fostering primarily skills and punctuality and accuracy as values, and much less divergent thinking, creativity and authentic arts poetics. Although such 
academic conception was supported in the past, the approaches like this could also be identified in the contemporary styles of education especially in the implicit pedagogy of teachers. Humanistic ideas as inherent by their nature to the idea of creation and creativity, as synonyms for free, natural development of the child's personality, have found its application in the preschool programs particularly in two models of the Essentials of upbringing-educational work in the day care institution, so-called A model and B model, first time were effected in 1996 [1] and then 2006 [8]. These programs have been compared in details in the published research work [6] where were included analysis of relations between upbringing-educational programs as the most important factors that affected development of the children`s creativity, and program contents, aims, and activities in this field, as well as repercussions of these approaches. Analysis results and comparisons of the arts education programs in the A model and B model were linked directly with influence to the children`s creative development [5].

Special contribution to the arts education development was given by Bogomil Karlavaris [11] who emphasized the importance of creative activities in the integral development of the child where important role belonged to arts education. Their holistic ideas have coloured our educational reality in the second half of $20^{\text {th }}$ century when the best results in this field have been achieved [14]. Important role in these programs belonged to adults, in this case teachers, in order to achieve aims and contents through motivation and designed activities in the work with the youngest. As contribution to creation of stimulating environment in preschool institutions that simultaneously could support not only the knowledge and skills but entire individuality of the child, it is expected that preschool institutions with creative, efficient and highly motivated teachers secure supporting environment through their programs. Current changes in the educational system are aimed to support different creative activities for children and requests that teacher realizes on daily basis activities stimulating creative expressions, performances and research in children. [3, pp. 15-27].
Based on the results of this research work it was not established the statistically significant difference of the gender influence, i.e. the female children did not express statistically significantly better results than male children within the model, but differences between results existed due to their dependence on the model. It also was showed that interaction, or combination of factor - model and factor gender did not affect the creativity in children. Therefore, the critical role had the quality of the model B and not gender of the children, which had been assumed possibility regarding globally established fact that female children had been developed faster than male children in that age which could be mirrored in the arts creativity in children. In the total variant as variability expression, the factor- model was the one explaining obtained differences including the children in the B model that have expressed better results at the Williams creativity test in comparison with children involved in the $\mathrm{A}$ model.

Conclusions. Based on the obtained results in this and other research works, which results go in favour of statement that children need full-valued and systematic support in the most important time of their development, especially when we speak of creative development in the context of the integral child s personality development, the cognitivedevelopmental programs and concepts are proved as the optimal way of systemic influence to the children's development with respect of all individual characteristics, needs and abilities in preschool children. Knowledge of educational and upbringing scope of different approaches can serve as pedagogic and methodological base for responding the question: which factors, in which way and to which extent play the role in the children's fine arts creativity development? Answer to this question is critical for selection and corresponding implementation of the upbringing-educational work, as well as for scientific establishment of the teaching methodology activities improving children's fine arts creativity. Therefore this research opens new research questions in the scope of children's development especially regarding creativity and creations in the early develop- 
ment to which the contemporary pedagogic theory and practice are focused.

Информация о конфликте интересов: авторы не имеют конфликта интересов для декларации.

Conflicts of Interest: the authors have no conflict of interests to declare.

\section{References}

1. Basics of Preschool Program of Upbringing and Education of Children between 3-7 Years of Age (1996), Educational Review, Belgrade, Serbia.

2. Bogdanova, M. (2017), Cognitive science: from multidisciplinary to Interdisciplinary, International Journal of Cognitive Research in Science, Engineering and Education, 5(2), pp. 145-150.

3. Đurđanović, M. and Stošić, I. (2017), Preschool teachers and their levels of interest in developing musical competencies, Facta Universitatis, Series Visual Arts and Music, 3(1), pp. 15-27.

4. Filipović, S. (2011), The Teaching Methodology of Arts Education, University of Arts and Publishing House KLETT, Belgrade, Serbia.

5. Filipović, S. (2016), The Comparative Analysis of Program Conceptions in the Field of Arts Education, in Sarajlić C. D. (Ed.) Traditional and Modern in the Fine Arts and Education, Faculty of Arts, University of Prishtina, Kosovska Mitrovica.

6. Filipović, S. (2009), Development and Understanding on Children's Arts Education and Possibilities of Upbringing-Educational Acting to it (doctoral dissertation), Academy of Arts, University of Banja Luka, Republic of Srpska, Banja Luka.

7. Filipović, S. and Kamenov, E. (2009), Results of Different Programs of Arts Education in Preschool Children, Proceedings of the Faculty of
Philosophy, in Gajić O. (Ed.) European dimension systems of education, Research and development, Proceedings №. 5, University of Novi Sad Novi Sad, 355-365.

8. General Basics of the Preschool Program (2006), Educational Review, Belgrade, Serbia.

9. Kamenov, E. (1990). Preschool Pedagogy, Institute for Textbooks and Teaching Resources, Belgrade, Serbia.

10.Kamenov, E. (2006), Model B The Model $B$ of preparatory preschool program. Novi Sad: Dragon, Serbia.

11.Karlavaris, B. (1960), The New Conception of the arts education, Institute for the Publishing of Textbooks of the People's Republic of Serbia, Belgrade, Serbia.

12.Piaget, J. (1957), Learning and Development, Pre-school child, Belgrade, Serbia.

13.Rousseau, J.J. (1762), Emily, or about the education, Bookstore Rajkovic and Curković, Belgrade, Serbia.

14.Spasojević, M. (2004), 50. The Anniversary of the Centre for Arts Education for Children and Youth in Vojvodina, Centre for Arts Education for Children and Youth in Vojvodina, Novi Sad, Serbia.

15.Tunik, E.E. (2003), Creativity Assessment Williams, Reč, Sankt-Peterburg, Russia.

16.Williams, F.E. (1980), Creativity Assessment Packet (CAP) 1980. New York: D. O. K. Publishers Inc. Buffalo, USA.

\section{Данные автора:}

Саня Филипович, кандидат технических наук, профессор кафедры теоретических предметов

\section{About the author:}

Sanja Filipović, Candidate of Technical Sciences, Professor of the Department of Theoretical Subjects 